\title{
Hubungan Riwayat BBLR Dengan Pekembangan Anak Prasekolah (Usia 4-5 Tahun) Di TK Dharma Wanita III Karangbesuki Malang
}

\section{Relationship between History of Low Birth Weight and Development of Preschoolers (4-5 Years old) in TK Dharma Wanita III Karangbesuki Malang}

\author{
Syafi'atur Rosyidah*1 ${ }^{1}$, Trias Mahmudiono ${ }^{1}$
}

\begin{abstract}
ABSTRAK
Latar Belakang : Masih ditemukan sebanyak 5-10\% anak usia 0-5 tahun yang mengalami keterlambatan perkembangan di Indonesia. Anak dengan riwayat berat lahir rendah memiliki risiko lebih besar mengalami gangguan perkembangan, terutama jika tidak diimbangi dengan pemberian stimulasi yang adekuat.

Tujuan: Penelitian ini bertujuan untuk menganalisis hubungan antara riwayat berat badan lahir rendah dengan perkembangan anak usia prasekolah (4-5 tahun) di TK Dharma Wanita III Karang Besuki Kota Malang.

Metode: Penelitian ini bersifat obervasional dengan rancang bangun cross-sectional. Populasi penelitian ini adalah seluruh siwa TK Dharma Wanita III Karangbesuki Malang yang berusia 4-5 tahun dengan kriteria inklusi siswa/siswi bersedia mengikuti skrining perkembangan atas persetujuan orang tua siswa, dan masih memiliki buku KIA atau KMS. Kriteria eksklusi dalam populasi penelitian ini adalah siswa yang orang tuanya tidak dapat ditemui pada saat penelitian. Jumlah sampel 32 yang diambil dengan teknik simple random sampling dan dianalisa menggunakan fisher exact .Data riwayat BBLR didapatkan melalui buku KIA atau KMS siswa, dan perkembangan anak di nilai melalui metode DDST (Denver Development screening test).

Hasil: Sebanyak $18.8 \%$ responden memiliki riwayat BBLR. Perkembangan anak prasekolah (usia 4-5 tahun) di TK Dharma Wanita III Malang yang berada dalam kategori normal sebesar $65,6 \%$, dan yang berada dalam kategori suspect sebesar $34,4 \%$. Terdapat hubungan antara riwayat BBLR dengan perkembangan anak usia prasekolah (Usia 4-5 Tahun) $(p=0.011)$.

Kesimpulan: Terdapat hubungan antara riwayat BBLR dengan perkembangan anak usia prasekolah (Usia 4-5 Tahun) di TK Dharma Wanita III Karangbesuki Malang. Siswa yang memiliki riwayat BBLR disarankan untuk diberikan perhatian khusus dan dilakukan deteksi dini perkembangan anak secara rutin agar gangguan perkembangan yang mungkin terjadi dapat segera dikenali dan segera mendapatkan tata laksana.
\end{abstract}

Kata kunci: anak prasekolah, perkembangan, riwayat BBLR. 


\section{ABSTRACT}

Background: Around 5-10\% children aged 0-5 years in Indonesia experienced developmental delays. Children with a low birth weight history have a greater risk of developing developmental disorders, especially they who not get more stimulation.

Objectives: The purpose of this study is to analyze the relationship between the histories of low birth weight with the development of preschoolers (4-5 years) in kindergarten Dharma Wanita III Karang Besuki Malang.

Methods: This study used cross-sectional design. Population on this study was all of students of TK Dharma Wanita III Karangbesuki Malang who was 4-5 years old, willing to join development screening test with their parent's permission, and have KIA book or KMS. Exclution criteria was student whose parents can't joint this research. Number of sample were 32 taken with simple random sampling technique and analyzed using fisher exact. History of BBLR Data collected from KIA book or KMS, Children Development data collected from Denver Development screening test.

Results: The results showed that $18.8 \%$ of respondents have a history of Low Birth Weight. The development of preschoolers (aged 4-5 years) in TK Dharma Wanita III Malang which were in the normal category $65.6 \%$, and who are in the category of suspect were $34.4 \%$. There was significant correlation between the history of LBW with the development of preschool age children (Age 4-5 Years) ( $p$-value $=0.011$ ).

Conclusion: There was significant correlation between histories of LBW with development of preschoolers (Age 4-5 Years) in TK Dharma Wanita III Karangbesuki Malang. Children who have a history of LBW suggested to be given special attention and early detection of child development on a regular basis to recognized some possible developmental disorders immediately and can immediately get the management.

Keywords: preschooler, development, history of LBW

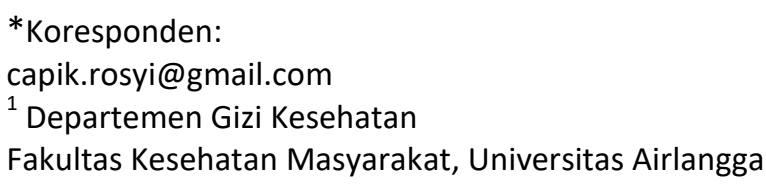

\section{PENDAHULUAN}

Usia prasekolah merupakan masa dimana seorang anak mudah menerima rangsangan. Pola perilaku dan sikap yang dibentuk pada awal kehidupan cenderung menetap.Usia 0 - 5 tahun merupakan priode keemasan pada siklus hidup manusia, dimana perkembangan anak pada usia tersebut berkembang dengan pesat. Perkembangan merupakan kemampuan fungsi tubuh yang merupakan hasil dari pematangan seseorang dan bersifat kompleks, perkembangan anak yang terjadi meliputi aspek kognitif, motorik, bahasa serta sosial ${ }^{1}$.

Anak usia dini mengalami perkembangan yang sangat pesat, $50 \%$ perkembangan anak terjadi pada usia 4 tahun, mencapai $80 \%$ pada usia 8 tahun hingga mencapai $100 \%$ ketika seseorang berusia 18 tahun. Di Indonesia, masih ditemukan sebanyak $5-10 \%$ anak usia 0-5 tahun yang mengalami keterlambatan perkembangan ${ }^{2}$. Gangguan perkembangan yang terjadi pada anak usia prasekolah dapat menetap dalam kehidupannya. Anak yang mengalami gangguan perkembangan dapat berdampak negatif pada psikososial anak, kemampuan kognitif, sosialisasi dan terbatasnya kemampuan pemecahan masalah serta kemampuan emosi pada anak ${ }^{3}$. Dampak tersebut dapat menetap sampai dewasa sehingga mempengaruhi status sehat individu 
tersebut. Dimana menurut WHO di sebutkan bahwa sehat tidak hanya terbebas dari gangguan fisik saja, melainkan juga mencakup kondisi mental dan sosial seseorang ${ }^{4}$.

Perkembangan anak dipengaruhi oleh beberapa faktor sejak masa kehamilan, persalinan, serta setelah anak tersebut dilahirkan. Faktor yang menyebabkan gangguan perkembangan pada masa kehamilan seperti, nutrisi ibu hamil yang tidak adekuat, paparan radiasi, konsumsi obat obatan atau alcohol, infeksi TORCH. Faktor yang menyebabkan gangguan perkembangan pada masa persalinan meliputi persalinan dengan bantuan, prematuritas, asfiksia serta berat badan lahir rendah. Sedangkan faktor yang mempengaruhi perkembangan anak pada masa post natal meliputi status gizi anak, penyakit yang diderita, stimulasi lingkungan serta faktor psikososial ${ }^{5}$.

Faktor prenatal dan natal yang mempengaruhi perkembangan anak salah satunya adalah berat lahir. Diperkirakan sebanyak $10-15 \%$ bayi prematur atau dengan berat lahir rendah mengalami gangguan perkembangan, serta bayi yang lahir dengan berat lahir sangat rendah berisiko 3-4 kali lebih besar untuk mengalamai gangguan perkembangan. Bayi dengan berat lahir rendah memiliki kelainan otak yang dapat diamati melalui MRI serta berisiko lebih besar mengalami kelainan sinyal dengan jumlah yang lebih besar. Selain itu bayi dengan berat lahir rendah, prematur, dan berat lahir sangat rendah memiliki kadar serum CRP yang lebih tinggi. CRP adalah protein plasma yang terlibat dalam respon inflamasi dan diproduksi saat terjadi kematian atau cedera sel. Artinya kematian sel otak, cedera sel otak, atau inflamasi pada sel otak pada bayi prematur, BBLR, BBLSR lebih tinggi dibandingkan dengan bayi yang lahir normal. Kelainan ini dapat menetap dan berdampak sampai bayi berusia remaja ${ }^{6}$.

Bayi berat lahir rendah adalah bayi yang lahir dengan berat kurang dari 2500 gram. Saat ini diperkirakan sebesar $16 \%$ bayi didunia lahir dengan berat badan lahir rendah dan $90 \%$ bayi yang lahir dengan berat badan lahir rendah berasal dari negara - Negara miskin dan Negara berkembang. (WHO, 2014). Di
Indonesia, prosentase BBLR dari seluruh bayi lahir adalah sebesar $10.2 \%$. di Jawa Timur kejadian BBLR meningkat dari $10 \%$ pada tahun 2010 menjadi $11 \%$ pada tahun $2013^{7}$.

Bayi dengan BBLR memiliki risiko lebih besar untuk mengalami gangguan pertumbuhan maupun perkembangan pada masa kanak - kanak. Anak dengan riwayat BBLR memiliki risiko mengalami gangguan pertumbuhan sampai dengan usia 2 tahun dan berisiko mengalami gangguan perkembangan pada 5 tahun pertamakehidupannya terutama jika tidak diimbangi dengan pemberian stimulasi yang lebih?

Berdasarkan hasil studi pendahuan di TK Dharma Wanita III Karang Besuki Kota Malang di diketahui bahwa ada beberapa siswa yang mengalami gangguan pemusatan perhatian serta keterlambatan perkembangan bahasa. Penelitian - penelitian yang menggali tentang bayi berat lahir rendah dan hubungannya dengan pertumbuhan anak, namun belum banyak penelitian yang dikembangkan untuk mengkaji hubungan antara BBLR dengan perkembangan anak. Tujuan penelitian ini adalah untuk menganalisis hubungan antara riwayat berat badan lahir rendah dengan perkembangan anak usia prasekolah (4-5 tahun) di TK Dharma Wanita III Karang Besuki Kota Malang.

\section{METODE}

Penelitian ini merupakan penelitian analitik observasional. Rancang bangun penelitian ini adalah cross-sectional, yaitu mempelajari status paparan dan outcome pada satu waktu. Lokasi penelitian di TK Dharma Wanita III Karangbesuki Malang. Penelitian dilakukan pada Mei - Juni 2014.

Populasi dalam penelitian ini adalah seluruh siswa TK Dharma Wanita III Karangbesuki Malang yang berusia 4-5 tahun sebanyak 34 orang, dengan kritria inklusi siswa/siswi bersedia mengikuti skrining perkembangan atas persetujuan orang tua siswa, dan masih memiliki buku KIA atau KMS. Kriteria eksklusi dalam populasi penelitian ini adalah siswa yang orang tuanya tidak dapat ditemui pada saat penelitian. Sampel dalam penelitian ini adalah sebagian siswa kelas A TK 
Dharma Wanita III Karangbesuki Malang. Besar sampel dihitung dengan rumus lemeshow dan didapatkan sampel sebesar 32 orang. Metode pengambilan sampel yang digunakan adalah simple random sampling.

Variabel bebas dalam penelitian ini adalah riwayat BBLR dan variabel tergantung pada penelitian ini adalah perkembangan anak. Sumber data dalam penelitian ini adalah data primer dan data sekunder. Data sekunder didapatkan dari TK Dharma Wanita III Karangbesuki Malang berupa daftar nama siswa Kelas A serta tanggal lahir dan riwayat BBLR yang diperoleh dari Buku KIA atau KMS Siswa yang disimpan oleh pihak TK Dharma Wanita III Karangbesuki Malang. Penelitian ini menggunakan Instrument perkembangan DDST II (Denver Development Screening Test II) untuk mendeteksi perkembangan anak. Pengukuran perkembangan anak dilakukan sekali dan tidak dilakukan pemeriksaan ulang pada kelompok anak yang memiliki perkembangan suspect. Skrining perkembangan dilakukan langsung oleh peneliti dengan di damping oleh masing masing orang tua siswa. Data karakteristik orang tua diperoleh melalui kuesioner yang ditanyakan oleh peneliti secara langsung kepada orang tua siswa.

Analisis data univariat dilakukan dengan menggunakan tabel distribusi frekuensi untuk mendapatkan gambaran karakteristik responden, serta untuk menggambarkan masing - masing variabel. Analisis data untuk mengetahui hubungan antara variabel riwayat BBLR dengan perkembangan anak prasekolah (usia 4-5 tahun) menggunakan uji Fisher exact dengan dengan bantuan aplikasi komputer.

\section{HASIL DAN PEMBAHASAN}

\section{Karakteristik Anak}

Jenis kelamin siswa kelas A TK Dharma Wanita III Malang terdiri dari 53,1\% laki - laki dan $46,9 \%$ perempuan. Sebanyak $28,1 \%$ anak memiliki riwayat pendidikan PAUD dan sebanyak $71,9 \%$ tidak pernah menjalani pendidikan PAUD sebelumnya. Sebagian besar siswa tidak mendapatkan pendidikan usia dini sebelumnya. Hal ini dapat berpengaruh pada tingkat perkembangan anak. Hasil penelitian sebelumnya menunjukkan bahwa anak yang mengikuti kelompok bermain sejak dini bisa mencapai perkembangan yang lebih cepat dibandingkan anak yang tidak mengikuti ${ }^{5}$.

Model pembelajaran yang didapatkan anak saat disekolah juga dapat mempengaruhi perkembangan anak. Pada Lokasi Penelitian ini, anak difasilitasi untuk mengembangkan kemampuan sesuai dengan tahapan perkembangan, secara umum tenaga pengajar di TK Dharma Wanita III Malang telah memenuhi kualifikasi untuk menjadi tenaga pengajar. Tenaga pengajar memiliki latar belakang pendidikan Sarjana PGMI dan Magister Psikologi dengan beberapa pengalaman pelatihan di bidang edukasi anak usia dini. Dengan kualifikasi tersebut, tenaga pengajar di lokasi penelitian dianggap mampu menstimulasi dan mendorong siswanya untuk belajar dan berkembang sesuai dengan tugas perkembangan sesuai usianya. Sebuah penelitian menyebutkan bahwa anak dengan pendidikan usia dini akan mendapatkan stimulasi perkembangan yang lebih baik dibandingkan anak yang tidak mengikuti pendidikan usia dini. Kualitas tenaga pengajar yang baik pada anak akan mengoptimalkan perkembangan anak di sekolah ${ }^{8}$. Faktor lingkungan merupakan salah satu faktor penting dalam perkembangan anak, anak dapat belajar melalui lingkungan disekitarnya yang meliputi kondisi sosial, pengasuhan orang tua, serta stimulasi oleh guru disekolah ${ }^{9}$.

\section{BBLR, Pola Asuh Orang Tua, dan Perkembangan Anak}

Berdasarkan Tabel 1 dapat diketahui bahwa $71,9 \%$ orangtua menerapkan pola asuh Demokratis yaitu pola asuh Orang tua yang memberikan pengertian dasar yang kuat pada anaknya. Mereka menyeimbangkan dukungan dengan struktur dan bimbingan. Tidak ada orangtua yang menerapkan pola asuh dominasi dan Penelantar. Pola asuh Dominasi ialah pola asuh dimana tuntutan orangtua terlalu tinggi, tidak realistis, berlatar penolakan terhadap nak. Orang tua sering menerapkan hukuman terhadap anak. Sedangkan pola asuh Penelantar ialah pola asuh dimana tidak ada tuntutan terhadap 
anak disebabkan orangtua mengabaikan. Tidak ada perhatian terhadap anak dan juga tidak ada hukuman. Pola ini berlatar belakang pada penolakan terhadap anak ${ }^{10}$. Orang tua dengan pola asuh penelantar tidak memberikan stimulasi perkembangan pada anak dengan optimal, akibatnya anak dengan risiko gangguan perkembangan dapat mengalami gangguan perkembangan akibat kurang baiknya faktor lingkungan keluarga pada anak tersebut, sehingga pengalaman belajar pada anak kurang dan stimulasi perkembangan yang mereka dapatkan juga kurang optimal ${ }^{9}$.

Tabel 1. Distribusi Frekuensi Tipe Pola Asuh Orangtua siswa, Riwayat BBLR dan Perkembangan Anak Usia Prasekolah (Uisa 4-5 tahun) di TK Dharma Wanita III Malang

\begin{tabular}{lcc}
\hline \multicolumn{1}{c}{ Variabel } & $\mathbf{n}$ & (\%) \\
\hline Pola Asuh Orang tua & & \\
$\quad$ Otoriter & 5 & 15,6 \\
$\quad$ Demokratis & 23 & 71,9 \\
$\quad$ Permisif & 4 & 12,5 \\
\hline $\begin{array}{l}\text { Riwayat BBLR } \\
\quad \text { Ya }\end{array}$ & 6 & 18,8 \\
$\quad$ Tidak & 26 & 81,3 \\
\hline Perkembangan Anak & 21 & 65,5 \\
$\quad$ Normal & 11 & 34,4 \\
$\quad \begin{array}{l}\text { Suspectgangguan } \\
\text { perkembangan }\end{array}$ & & \\
\hline Total & 32 & 100 \\
\hline
\end{tabular}

Dari hasil penelitian ditemukan sebanyak $18,8 \%$ responden memiliki riwayat BBLR. lebih tinggi dibanding dengan prevalesnsi BBLR di Indonesia berdasarkan hasil Riskesdas tahun 2013 yaitu sebesar 10,2\%. angka ini juga lebih tinggi jika dibandingkan dengan kejadian BBLR di Jawa Timur yaitu sebesar $11 \%$ dari seluruh kelahiran ${ }^{10}$. Hal ini dapat dipengaruhi oleh tingkat penghasilan orang tua, dari hasil penelitian ditemukan bahwa masih ada orang tua yang memiliki tingkat penghasilan golongan kurang dari Rp.1.000.000 yaitu sebesar 18,8\%, dimana angka ini berada dibawah nilai UMR Kota Malang tahun 2014 yaitu sebesar Rp.1.587.000. Tingkat ekonomi keluarga dapat mempengaruhi status gizi ibu pada saat kehamilan, dimana status gizi ibu saat hamil mempengaruhi status gizi janin. Status ekonomi berpengaruh pada kemampuan orang tua dalam membeli dan memndapatkan makanan yang bernilai gizi tinggi, beberapa studi mengatakan bahwa pendapatan merupakan faktor yang sangat mempengaruhi kemampuan dalam memiliki kualitas dan kuantitas hidangan ${ }^{11}$. Asupan nutrisi merupakan salah satu faktor eksternal yang mempengaruhi perkembangan anak, gizi diperlukan dalam mendukung semua mekanisme biologis dan kimiawi dalam tubuh termasuk dalam otak. Kecukupan nutrisi ini dapat mempengaruhi kematangan otak seseorang ${ }^{12}$.

Faktor lain yang dapat mempengaruhi kejadian BBLR adalah tingkat pendidikan. Sebesar $18,8 \%$ orang tua siswa memiliki tingkat pendidikan SD dan $12,5 \%$ berpendidikan SMP. Ibu dengan tingkat pendidikan rendah berpeluang 12 kali lebih besar melahirkan bayi dengan berat lahir rendah. Ibu yang berpendidikan lebih tinggi berkemampuan menjaga kesehatan serta kehamilannya lebih baik dibandingkan ibu dengan tingkat pendidikan rendah ${ }^{10}$.

Perkembangan anak prasekolah (usia 45 tahun) di TK Dharma Wanita III Malang yang berada dalam kategori normal sebesar $65,6 \%$, dan yang berada dalam kategori suspect sebesar $34,4 \%$. Perkembangan anak yang berada pada kategori suspect tegolong tinggi.Anak yang mengalami gangguan perkembangan dan tidak segera ditangani dapat menimbulkan gangguan psikosial bagi anak tersebut ${ }^{10}$. Kondisi ini menggambarkan kondisi yang tidak sehat berdasarkan definisi sehat dari WHO yang menyatakan bahwa sehat merupakan kondisi yang sempurna baik fisik, mental maupun sosial, tidak hanya terbebas dari penyakit atau kelemahan/cacat dan tidak hanya terbebas dari penyakit atau cacat $^{13}$. Tingginya kasus ini maka akan berdampak pada status kesehatan masyarakat di lingkungan tersebut. 


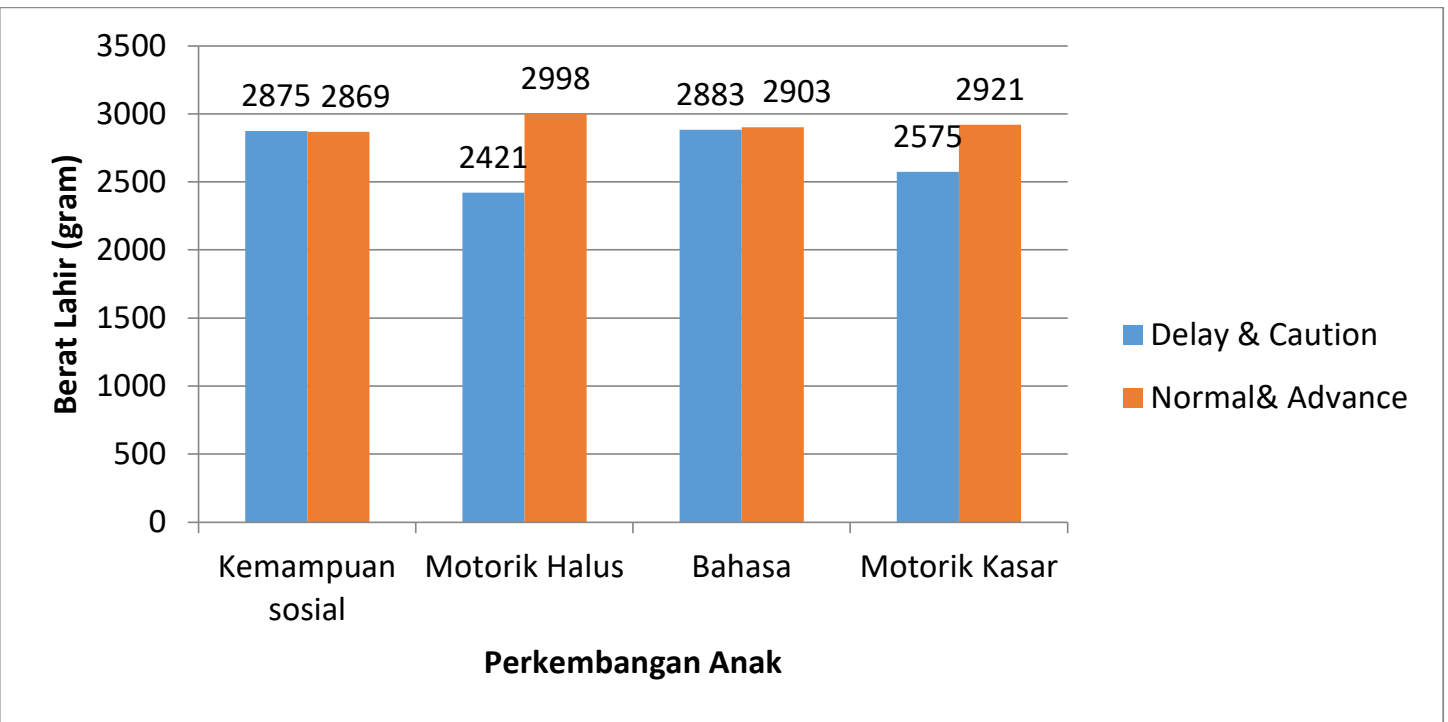

Gambar 1. Rata - Rata Riwayat berat lahir berdasarkan Perkembangan Anak Usia Prasekolah (Uisa 45 tahun) di TK Dharma Wanita III Malang

Tabel 2. Analisis Uji Perbedaan Riwayat Berat Badan Lahir Anak Berdasarkan Status Perkembangan

\begin{tabular}{lcc}
\hline \multicolumn{1}{c}{ Tugas Perkembangan } & Rata - Rata Berat Lahir & P value \\
\hline Kemampuan sosial & 2875 & \\
Delay \& Caution & 2869 & 0,974 \\
$\quad$ Normal \& Advance & & \\
\hline Motorik Halus & 2421 & 0,02 \\
$\quad$ Delay \& Caution & 2998 & \\
$\quad$ Normal \& Advance & & 0,948 \\
\hline Bahasa & 2883 & \\
$\quad$ Delay \& Caution & 2903 & 0,361 \\
$\quad$ Normal \& Advance & & \\
\hline Motorik Kasar & 2575 & \\
$\quad$ Delay \& Caution & 2921 & \\
$\quad$ Normal \& Advance &
\end{tabular}

Tabel 3. Hubungan Riwayat BBLR dengan Perkembangan Anak Usia Prasekolah (Uisa 4-5 tahun) di TK Dharma Wanita III Malang

\begin{tabular}{|c|c|c|c|c|c|c|c|}
\hline \multirow{3}{*}{ Riwayat BBLR } & \multicolumn{4}{|c|}{ Perkembangan } & \multirow{2}{*}{\multicolumn{2}{|c|}{ Jumlah }} & \multirow{3}{*}{$P$ value } \\
\hline & \multicolumn{2}{|c|}{ Normal } & \multicolumn{2}{|c|}{$\begin{array}{c}\text { Suspectgangguan } \\
\text { perkembangan }\end{array}$} & & & \\
\hline & $n$ & $\%$ & $n$ & $\%$ & $n$ & $\%$ & \\
\hline $\mathrm{Ya}$ & 1 & 3,1 & 5 & 15,6 & 6 & 18,8 & 0011 \\
\hline Tidak & 20 & 62,5 & 6 & 18,8 & 26 & 81,3 & 0,011 \\
\hline Total & 21 & 65,5 & 11 & 34,4 & 32 & 100 & \\
\hline
\end{tabular}

Berdasarkan Tabel 2 dapat dilihat bahwa hasil uji-t antaraberat badan lahir anak pada kelompok anak dengan perkembangan motorik halus yang normal \& advance dengan kelompok anak dengan kategori delay diperoleh $P$-value $=0.02<\alpha=0.05$ yang artinya adanya perbedaan yang signifikan antara nilai rata - rata berat badan lahir anak pada kelompok anak dengan perkembangan motorik halus yang normal \& advance dengan kelompok anak dengan kategori delay \& caution. Tidak ada Perbedaan yang signifikan antara nilai rata - rata berat badan lahir pada anak yang mengalami hambatan 
perkembangan dan perkembangan normal pada domain perkembangan motorik kasar dan bahasa. Meskipun demikian, dapat dilihat pada gambar 1 bahwa nilai rata - rata berat badan lahir anak pada kelompok normal \& advance lebih tinggi dibandingkan dengan anak pada kelompok delay \& caution pada tugas perkembangan motorik kasar dan bahasa.

Bayi dengan berat lahir rendah dapat mengalami kelainan struktur otak serta berisiko lebih besar mengalami kelainan sinyal dengan jumlah yang lebih besar jika dibandingkan dengan bayi yang memiliki berat lahir normal. Disamping itu, bayi dengan berat lahir rendah memiliki risiko inflamasi atau peradangan pada otak yang dapat mempengaruhi kualitas dan jumlah saraf dan sel yang ada pada otak. Hal ini akan mempengaruhi maturitas otak serta perekembangan individu ${ }^{12}$.

Tabel 3 menunjukkan hasil uji statistikantara variabel riwayat BBLR dengan perkembangan anak menggunakan fisher exact didapatkan nilai $p=0,011$. Hal ini berarti bahwa ada hubungan bermakna antara riwayat BBLR dengan perkembangan anak usia prasekolah (usia 4-5 tahun) TK Dharma Wanita III Malang. Perkembangan anak yang dikaji dalam penelitian ini terdiri dari perkembangan bahasa, motorik kasar, motorik halus serta kemampuan sosial anak. Hasil penelitian ini sejalan dengan penelitian sebelumnya yang menyatakan bahwa bayi dengan riwayat prematur atau dengan berat lahir rendah berisiko mengalami gangguan dalam perkembangan kognitif serta perkembangan motoriknya ${ }^{14}$. Penelitian lain juga menyebutkan bahwa bayi yang lahir dengan berat badan rendah berpotensi untuk mengalami gangguan perkembangan dimasa anak yang akan datang. Bayi yang lahir dengan berat lahir rendah, utamanya pada bayi yang lahir dengan berat lahir sangat rendah dapat mengalami abnormalitas pada stuktur otak. Kondisi abnormal pada otak di masa bayi tersebut dapat mempengaruhi perkembangan anak dimasa mendatang ${ }^{15}$.

\section{KESIMPULAN}

Berdasarkan hasil penelitian dan pembahasan yang telah diuraikan, dapat disimpulkan bahwa terdapat hubungan antara riwayat BBLR dengan perkembangan anak prasekolah (usia 4-5 tahun) di TK Dharma Wanita III Malang.Stimulasi perkembangan pada anak Usia Prasekolah (Usia 4-5 tahun) di TK Dharma Wanita III Malang diharapkan untuk lebih dioptimalkan lagi untuk meminimalisir kejadian gangguan perkembangan pada anak, terutama pada anak dengan riwayat BBLR.

Anak yang berada pada kategori suspect diharapkan selanjutnya bisa mendapatkan stimulasi perkembangan yang optimal dari guru dan orang tua dan dilakukan skrining perkembangan secara rutin untuk memastikan anak tersebut dapat mencapai tugas perkembangan sesuai dengan usianya. Setelah diberi stimulasi perkembangan yang optimal, diharapkan anak dapat menyelasikan tugas perkembangan sesuai dengan usianya dan tidak berlanjut dan menetap sebagai kelainan atau gangguan perkembangan pada anak tersebut. Jika gangguan perkembangan masih menetap diharapkan anak bisa memperoleh pemeriksaan lebih lanjut oleh Dokter spesialis Anak dan mendapatkan penanganan yang adekuat.

Siswa yang memiliki riwayat BBLR disarankan untuk diberi perhatian khusus dan dilakukan deteksi dini perkembangan anak secara rutin agar gangguan perkembangan yang mungkin terjadi dapat segera dikenali dan segera mendapatkan tata laksana.

\section{ACKNOWLEDGEMENT}

Peneliti mengucapkan terima kasih kepada Kepala sekolah TK Dharma Wanita III Karangbesuki Malang memberikan izin untuk dijadikan tempat penelitian sehingga penelitian ini dapat terlaksana serta adekadek siswa TK Dharma Wanita III Karangbesuki Malang yang telah meluangkan waktu membantu penelitian ini. 


\section{REFERENSI}

1. Santri, A., Idriansari, A. \& Girsang, B. M. FAKTOR-FAKTOR YANG MEMPENGARUHI PERTUMBUHAN DAN PERKEMBANGAN ANAK USIA TODDLER (1-3 TAHUN) DENGAN RIWAYAT BAYI BERAT LAHIR RENDAH. J. Ilmu Kesehat. Masy. 5, 63-70 (2014).

2. Datar, A. \& Jacknowitz, A. Birth Weight Effects on Children's Mental, Motor, and Physical Development: Evidence from Twins Data. Matern. Child Health J. 13, 780-794 (2009).

3. Moonik, P., Hesti L.H., Rocky, W. Faktorfaktor yang mempengaruhi keterlambatan perkembangan anak taman kanak-kanak. e-Clinic (eCl) 3, 124132 (2015).

4. Rose, J. et al. Neonatal physiological correlates of near-term brain development on MRI and DTI in very-lowbirth-weight preterm infants. Neurolmage Clin. 5, 169-177 (2014).

5. Maimon, E., Ismail, D. \& Sitaresmi, M. N. Hubungan Mengikuti Kelompok Bermain dan Perkembangan Anak. Sari Pediatr. 15, 232 (2016).

6. Chamidah A. Nur. Deteksi Dini Gangguan Pertumbuhan dan Perkembangan Anak. J. Pendidik. Khusus 4, 83-93 (2009).

7. Rahayu, L. S. \& Sofyaningsih, M. Pengaruh BBLR (Berat Badan Lahir Rendah) dan Pemberian ASI Eksklusif terhadap Perubahan Status Stunting pada Balita di Kota dan Kabupaten Tangerang Provinsi Banten. in Peran Kesehatan Masyarakat dalam Pencapaian MDG's di Indonesia 160-169 (2011).

8. Bradley, R. H. \& and Robert F. Corwyn.
Socioeconomic Status and Child Development. Annu. Rev. Psychol. 53, 371-399 (2002).

9. Azwar, S. Sikap Manusia, Teori dan Pengukuranya. (Pustaka Belajar, 2010).

10. Hildyard, K. L. \& Wolfe, D. A. Child neglect: developmental issues and outcomes ir Child Abuse Negl. 26, 679695 (2002).

11. Khairina, M. . Faktor-faktor yang Berhubungan dengan Kejadian Bayi Berat Lahir Rendah ( BBLR ) di Wilayah Kerja Puskesmas Kecamatan Cipayung Kota Depok Provinsi Jawa Barat Tahun 2013. (2013).

12. Shenkin, S. D., Starr, J. M. \& Deary, I. J. Birth Weight and Cognitive Ability in Childhood: A Systematic Review. Psychol. Bull. 130, 989-1013 (2004).

13. World Health Organization. WHO I Constitution of WHO: principles. WHO (2016).

14. Oudgenoeg-Paz, O., Mulder, $H_{\text {., }}$ Jongmans, M. J., van der Ham, I. J. M. \& Van der Stigchel, S. The link between motor and cognitive development in children born preterm and/or with low birth weight: A review of current evidence. Neurosci. Biobehav. Rev. 80, 382-393 (2017).

15. Luttikhuizen dos Santos, E. S., de Kieviet, J. F., Königs, M., van Elburg, R. M. \& Oosterlaan, J. Predictive value of the Bayley Scales of Infant Development on development of very preterm/very low birth weight children: A meta-analysis. Early Human Development 89, 487-496 (2013). 